\title{
Degradation of Diesel, a Component of the Explosive ANFO, By Bacteria Selected From an Open Cast Coal Mine in La Guajira, Colombia
}

Jenny Dussán* and Mónica Numpaque

Centro de Investigaciones Microbiológicas-CIMIC, Departamento de Ciencias Biológicas, Universidad de los Andes, Bogotá, Colombia.

\begin{abstract}
Open cast coal mining operations involve the use of the explosive Ammonium Nitrate Fuel Oil (ANFO) for detonation processes. Five bacterial strains belonged to Pseudomonas $s p$ and Pseudomonas stutzeri were isolated from an open cast coal mine located in La Guajira, Colombia. Degradation of the second component of ANFO, which is diesel, by the five isolates and by a consortium was evaluated. The biodegradation of diesel was determined by gas chromatography with a flame ionization detector. Biodegradation Efficiency (BE) was $96 \%$ for the consortium; individual strains had levels between $10-95 \%$ of $\mathrm{BE}$. Analysis for the presence and expression of the alkane monooxygenase gene involved in the degradation of diesel was evidenced in two strains showing band size products between $500-600 \mathrm{bp}$. Results suggest that these bacteria are candidates for diesel bioremediation.
\end{abstract}

Keywords: Pseudomonas; Diesel; Biodegradation; Alkane Monooxygenase

\section{Introduction}

Open cast coal mining requires the removal of surface materials and soil to expose sources of coal. The explosive ANFO, composed of $96 \%$ ammonium nitrate and $4 \%$ diesel fuel, is used for detonation processes in coal mining. Part of the explosive ANFO is deposited in the soil where certain microorganisms are able to survive under these extreme conditions.

Diesel is composed of saturated hydrocarbons such as paraffin, and aromatic hydrocarbons. Some microorganisms are able to use hydrocarbons as an energy source, in fact bacteria have been reported in remediation of diesel contaminated soils, including Pseudomonas stutzeri [1] and Pseudomonas aeruginosa [2], among others. The ability of bacteria to degrade soil pollutants such as hydrocarbons is useful for bioremediation purposes and their ability to emulsify hydrocarbons has been studied to this respect, making bacteria useful in the removal of these compounds from the environment [3].

Alkane monooxygenase enzyme has been studied in diesel degrading micro organisms, it is responsible for the conversion of alkanes into acetyl-CoA. The model for alkane degradation has been described for Pseudomonas putida Gpo1, which has the OCT plasmid [4].

Six bacterial strains were selected from ANFO-contaminated soil, sampled at an open cast coal mine in La Guajira, Colombia. Bacteria were isolated from two locations at the coal mine, known as Patilla and Tabaco. Patilla has been operating for several years and Tabaco belongs to a new area of exploration. Four strains were isolated from the Tabaco pit and two strains from the Patilla pit. The isolates belong to Pseudomonas sp, Pseudomonas stutzeri and Arthrobacter sp. Microorganisms were chosen on the basis of being able to use ANFO as an alternative nitrogen and carbon source, as well as being resistant to its exposure. The purpose of this study was to determine the ability of the six strains selected from the coal mine, to degrade diesel as a carbon energy source as well to determine the presence and expression of the alkane monooxygenase gene (alkB) involved in the degradation of diesel.

\section{Materials and Methods}

\section{Bacterial strains and growth conditions}

Six bacterial strains were isolated from ANFO-contaminated soil.
Samples were collected from two pits: Patilla (strain: PRIII and PQII) and Tabaco (strains: TRI, TRII, TRIII, TRIV), at a coal mine in La Guajira, northeast Colombia $\left(11^{\circ} 5^{\prime} 22^{\prime \prime} \mathrm{N}, 72^{\circ} 40^{\prime} 31^{\prime \prime} \mathrm{W}\right)$. Strains were identified as Pseudomonas sp (PRIII and TRIV), Pseudomonas stutzeri (TRI, TRII and TRIII) and Arthrobacter sp (PQ II) according to the V3 to V5 hypervariable region (16S rDNA) PCR method using $325 \mathrm{f}$ and $975 \mathrm{r}$ primer set, the PCR products were purified and sequenced using the BigDye ${ }^{\circledR}$ Terminator v3.1 Cycle Sequencing Kit. Sequences were assembled using BioEdit v7.0.9.

A selection pressure on solid medium was conducted in which strains were grown under a saturated diesel atmosphere. Strains were incubated at $30^{\circ} \mathrm{C}$ in a solid Minimal Salts Medium (MSM), with a composition of $\mathrm{KH}_{2} \mathrm{PO}_{4}(0.5 \mathrm{~g} / \mathrm{L}), \mathrm{Na}_{2} \mathrm{SO}_{4}(2.0 \mathrm{~g} / \mathrm{L}), \mathrm{KNO}_{3}(2.0 \mathrm{~g} / \mathrm{L})$, $\mathrm{CaCl}_{2}(0.001 \mathrm{~g} / \mathrm{L}), \mathrm{FeSO}_{4}(0.0004 \mathrm{~g} / \mathrm{L})$ and $\mathrm{MgSO}_{4} .7 \mathrm{H}_{2} 0(1.0 \mathrm{~g} / \mathrm{L})$. Diesel, a commercial product obtained from the coal mine, was supplied as the sole carbon source. Replica-plating was employed with all strains transferred to fresh media every 8 days for a total of 5 weeks of selection pressure. Strains that survived were kept in $10 \%$ glycerol at $-80^{\circ} \mathrm{C}$ for further analysis.

\section{Liquid pressure}

The number of cells per colony was established for each strain. Then 10 colonies from each strain were placed in a tight-lidded glass flask with $50 \mathrm{ml}$ of liquid MSM and $5 \mathrm{ml}$ of diesel. Each strain had three replicate flasks. Additionally, an abiotic control was made in triplicate. A consortium was formulated by inoculating equal proportions of all five strains in a flask in the same conditions as the individual tests. The consortium also had three replicate flasks. The 21 flasks were incubated at $30^{\circ} \mathrm{C}$ for 43 days. Bacterial growth was monitored on days $0,4,7,17$

*Corresponding author: Jenny Dussán, Centro de Investigaciones Microbiológicas-CIMIC, Departamento de Ciencias Biológicas, Universidad de los Andes, Bogotá, Colombia, Tel: (571)3394949; E-mail: jdussan@uniandes.edu.co

Received May 17, 2012; Accepted September 24, 2012; Published October 04 2012

Citation: Dussán J, Numpaque M (2012)Degradation of Diesel, a Component of the Explosive ANFO, By Bacteria Selected From an Open Cast Coal Mine in La Guajira, Colombia. J Bioprocess Biotech 2:126 doi: 10.4172/2155-9821.1000126

Copyright: @ 2012 Dussán J, et al. This is an open-access article distributed under the terms of the Creative Commons Attribution License, which permits unrestricted use, distribution, and reproduction in any medium, provided the original author and source are credited. 
and 43 by serial dilutions of each of the flasks. Data analysis of bacterial growth was conducted using SPSS 18.0 and graphs were drawn in Sigma Plot 10.0.

\section{Chromatography}

Diesel degradation on day 0 and day 43 was analyzed by gas chromatography with a flame ionization detector (CG-FID). The gas chromatographic analysis was implemented with a Shimadzu gas chromatograph GC-2014, equipped with a flame ionization detector (FID), a Shimadzu AOC-20i auto-injector, a splitless injection port, and a ZB 5\% phenyl-95\% dimethylpolysiloxane capillary column $(5.30 \mathrm{~m}$ x $0.25 \mathrm{~mm}$ x $0.25 \mu \mathrm{m}$ ), using GC Data System Solution Release 2.30 software. The injector and detector temperatures were kept at $250^{\circ} \mathrm{C}$ and $320^{\circ} \mathrm{C}$ respectively. The temperature program was as follows: $50^{\circ} \mathrm{C}$ (5 min) to $250^{\circ} \mathrm{C}(7 \mathrm{~min})$ to $7^{\circ} \mathrm{C} / \mathrm{min}$, then $10^{\circ} \mathrm{C} / \mathrm{min}$ to $294.3^{\circ} \mathrm{C}(10$ $\mathrm{min})$. Nitrogen was used as the carrier gas ( $99.995 \%$, Cryogen) at a flow rate of $14 \mathrm{~mL} / \mathrm{min}$. The biodegradation efficiency (BE) was calculated according to [5] using the equation: $\mathrm{BE}(\%)=100-(\mathrm{As} \times 100 / \mathrm{Aac})$ where $\mathrm{As}=$ total area of peaks in each sample, Aac=total area of peaks in the appropriate abiotic control, BE (\%)=efficiency of biodegradation.

Alkane monoxygenase expression: In order to compare alkane monoxygenase expression four of the strains were chosen, TRI and PRIII that showed the highest BE, TRII that showed the lowest BE and PQ II as a negative control because it was not able to grow under diesel pressure conditions after 17 days of treatment. These four strains were also grown in glass flasks with tight-fitting lids with $50 \mathrm{ml}$ of liquid MSM and $5 \mathrm{ml}$ of glucose $0.05 \%$ following the same procedure as the one described in Liquid pressure section.

Design of Primers for the Alkane Monoxygenase Gene (alkb): Primers for alkB were designed by using Primer3 program and checked by BLAST. Alkane monoxygenase gene sequence of Pseudomonas stutzeri were obtained from Genbank accession number AAV41375.1. These primers were alkb-f (5'-AACATAACCGTGGCCATCAC-3') and alkb-r (5'-AACACCACGCTGTACATCCA-3').

PCR Amplification: Template DNA was obtained from cells grown overnight in Luria Bertani (LB) broth at $30^{\circ} \mathrm{C} / 220 \mathrm{rpm}$. Cells were heat-lysed for $15 \mathrm{~min}$ and centrifuged for $2 \mathrm{mins}$ at $13000 \mathrm{rpm}$, $1.5 \mu \mathrm{L}$ of supernatant total DNA were placed in a reaction tube with PCR mixes constituted by $1 \mathrm{X}$ PCR buffer, $2.5 \mathrm{mM} \mathrm{MgCl}_{2}, 0.5 \mathrm{U}$ Taq polymerase, $0.2 \mathrm{mM}$ of dNTP's, and $0.3 \mu \mathrm{M}$ of each primer, in a final volume of $25 \mu \mathrm{l}$. PCR amplifications were carried out in an iCycler ${ }^{\mathrm{rm}}$ thermal cycler under the conditions: an initial step at $95^{\circ} \mathrm{C}$ for $4 \mathrm{~min}$, followed by 35 cycles of denaturation at $95^{\circ} \mathrm{C}$ for $45 \mathrm{~s}$, annealing at $55^{\circ} \mathrm{C}$ for $45 \mathrm{~s}$ for alkB primer pair and elongation at $72^{\circ} \mathrm{C}$ for $45 \mathrm{~s}$. A final extension cycle was run at $72^{\circ} \mathrm{C}$ for $10 \mathrm{~min}$. PCR products were analyzed by gel electrophoresis $1 \%$ agarose gels. Gels were stained with ethidium bromide and images were captured with a GelDoc imaging system (BioRad).

RNA extraction and RT-PCR amplification: RNA extraction from 7 day samples was made using ZR RNA MiniPrep ${ }^{\mathrm{TM}}$ kit (Zymo research) protocol. RNA quality was evaluated by $1 \%$ agarose gel electrophoresis and ethidium bromide staining and quantity by $260 / 280$ ratio using Nanodrop technologies. cDNA was obtained using 2 Step PCR Long Range $^{\mathrm{TM}}$ Kit (QUIAGEN) and random primers (Invitrogen). alkB gene was amplified from this cDNA following the same conditions described in PCR amplification. Products were purified with the Wizard ${ }^{\circledR}$ SV
Gel and PCR Clean-Up System kit and sequenced under BigDye ${ }^{\mathrm{TM}}$ terminator cycling conditions. High-quality sequences were compared to GenBank for a similarity analysis using BLAST.

\section{Results and Discussion}

\section{Monitoring of bacterial growth}

All six strains were able to grow under diesel pressure however strain PQII did not show growth at the 17 day of treatment. The number of cells for each flask was registered on days $0,4,7,17$ and 43 these results are shown in figure 1A. On the abiotic control there was no growth at all. Strains showed a decrease in growth in the first days of treatment as a result of the diesel selection pressure and adaptation to the selection media. These strains might be facultative oligotrophs due to the increase in cellular growth in the last days of the incubation period when nutrient-poor conditions exist. In fact, the coal mine with ANFO residues is an oligotrophic environment. The consortium showed the same growth behavior as these strains. These results suggest that strains used diesel as a carbon energy source. An analysis of variance (ANOVA) was performed to verify whether or not mean bacterial growth was equal between strains and days. The ANOVA showed significant differences in bacterial growth between days for all five strains and the consortium ( $\mathrm{p}$-value $<0.05)$.

Bacterial growth in strains TRI, TRII, PRIII and PQII was also evaluated by using glucose as the carbon source. The number of cells for each flask was registered in the same days and these results are

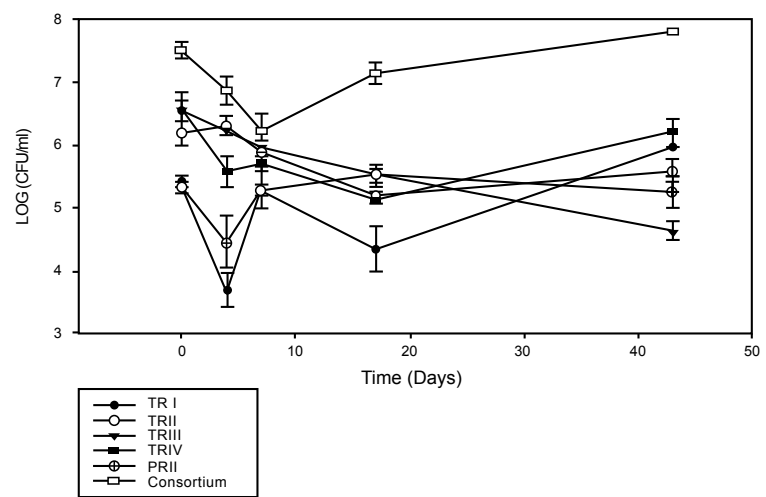

B

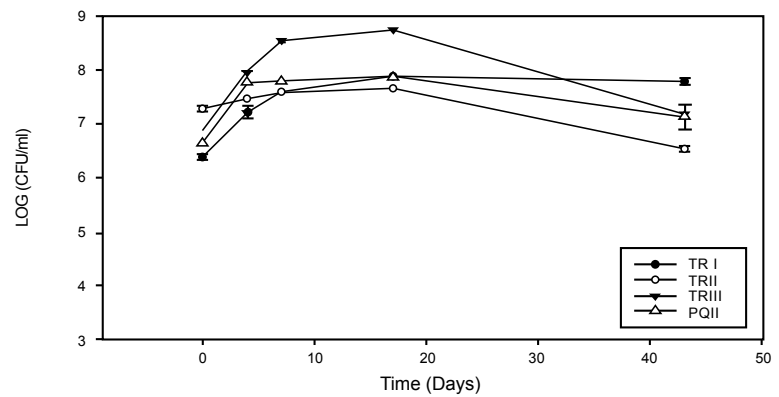

Figure 1: Monitoring of bacterial growth. A) Log values of Colony Forming Units per milliliter (CFU/ml) for all five strains and the consortium. Strains were incubated in liquid minimal salts medium (MSM) supplemented with diesel as the only carbon source at $30^{\circ} \mathrm{C}$ for 43 days. B) Log values of (CFU/ml) for strains (TRI, TR II, PR III, PQ II) incubated in MSM supplemented with glucose $(0.5 \%)$ as the only carbon source at $30^{\circ} \mathrm{C}$ for 43 days. Data are represented as the average of individual triplicate samples. Error bars represent standard error. 
A)

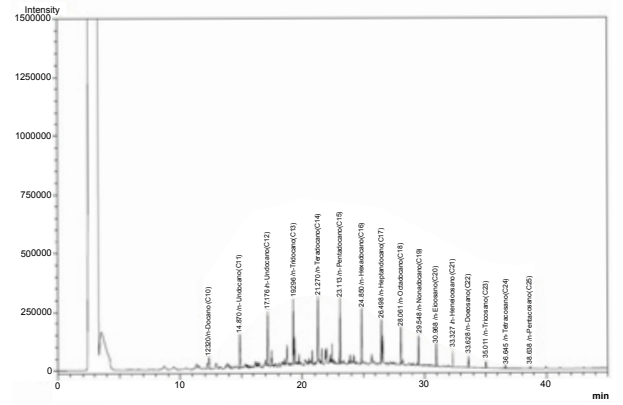

C)

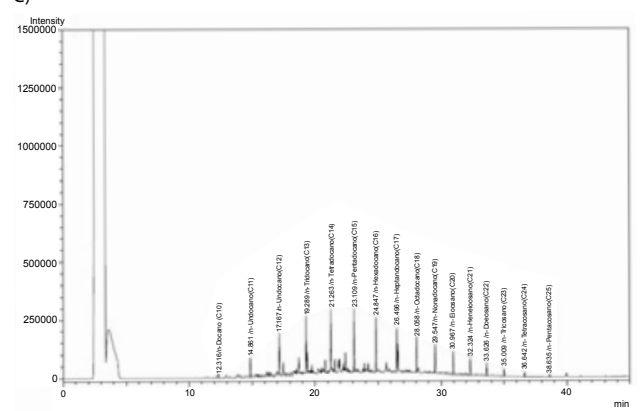

E)
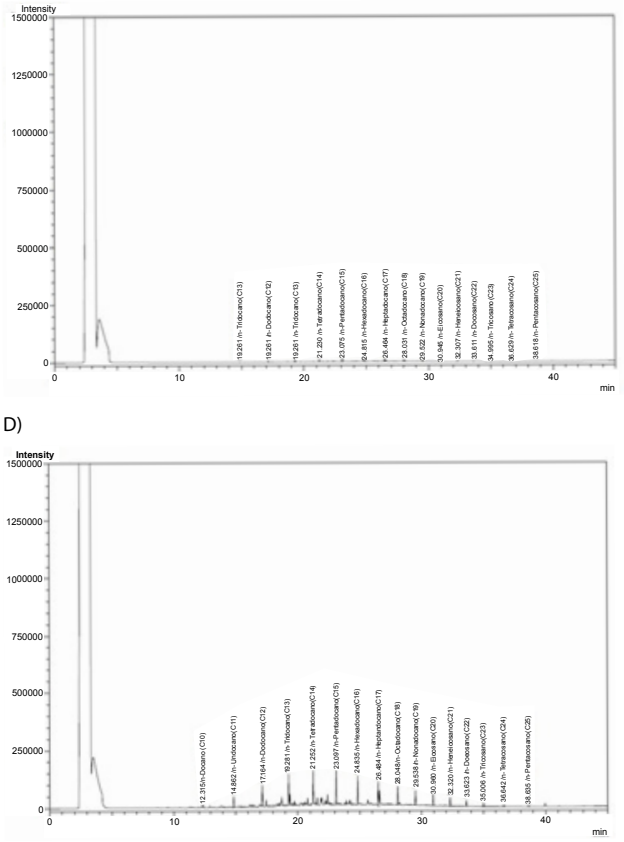

F)
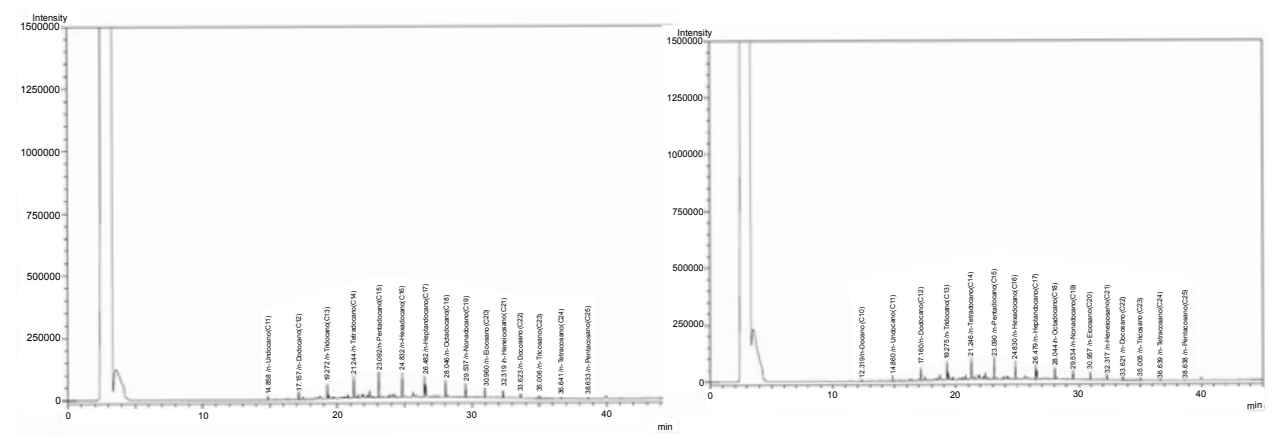

G)

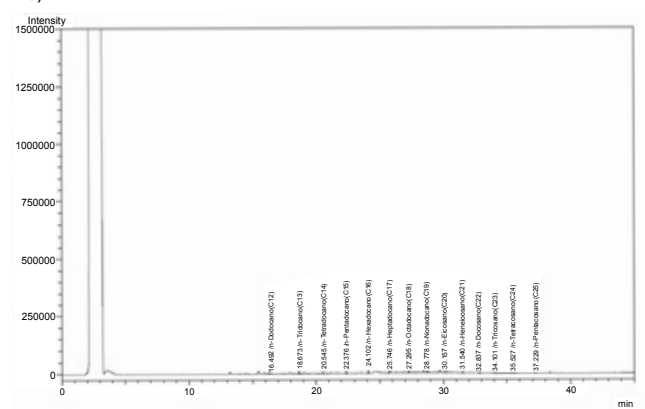

Figure 2: Diesel degradation. Gas Chromatography And Flame lonization Detector (GC/FID) analysis were made to evaluate the biodegradation of diesel components. GC profiles of all five strains and a consortium after 43 days of incubation in MSM with diesel as the only carbon source. (A) abiotic control, (B) inoculated with strain TRI, (C) inoculated with strain TRII, (D) inoculated with strain TRIII, (E) inoculated with strain TRVI, (F) inoculated with strain PRIII, (G) inoculated with the consortium.

shown in figure 1B. Growth on MMS with addition of glucose was higher than growth on MMS with diesel as a carbon source. This was expected because bacteria can easily use glucose as a carbon energy source. To obtain energy from glucose bacteria employ the glycolysis pathway composed of constitutive enzymes which are always produced by cells independently of the composition of the culture medium.

\section{Chromatography}

A GC/FID analysis was performed after 43 days of incubation to investigate the degradation of diesel. The biodegradation of diesel was evidenced by the reduction in the area under the hydrocarbon peaks in the chromatograms when compared to that of the abiotic control suggesting the removal of diesel components. Diesel is composed of 
hydrocarbons containing 10 to 24 carbon atoms. All strains showed a reduction in the area under the hydrocarbon peaks corresponding to 10 to 25 carbon atoms (C10 to $\mathrm{C} 25)$ when compared to the abiotic control (Figure 2). Strain PQII was not analyzed by GC/FID as it did not show growth at the 43 day of treatment. The consortium showed the greatest reduction in the total area under the peaks and thus the greatest biodegradation efficiency of $96 \%$, followed by strain TRI, at $95 \%$. PRIII and TRIV also had high BE values of $70 \%$ and $69 \%$, respectively, followed by TRIII with a BE of $52 \%$, and TRII with the lowest $\mathrm{BE}$ of $10 \%$. The peak corresponding to 10 carbon atoms disappeared entirely in the TRI and TRIV chromatograms. In the consortium chromatogram the peaks corresponding to 10 and 11 carbon atoms disappeared completely. The consortium chromatogram shows a decrease in the area under the hydrocarbon peaks when compared to the DRO standard (Figure 3). Studies report that the mineralization of hydrocarbons is potentiated by the co-existence and cooperation of a group of microorganisms, as is the case in a consortium [5]. Research has shown that the biodegradation rate is high because these bacteria are dealing with simple molecules, such as n-alkanes (C10, C11), however, the rate might be lower for branched alkanes, n-alkyl aromatics, cyclic alkanes and polynuclear aromatics [6]. These results indicate that the Pseudomonas strains employed in this study were able to degrade diesel. In fact, the Pseudomonas genus has been reported as one of the major hydrocarbon degrading groups in previous research [7].

\section{PCR amplification, RNA extraction and RT-PCR (reverse transcriptase) amplification}

In diesel biodegradation, the alkane degradation pathway has been reported as one of the principal methods used by microorganisms to degrade diesel [4]. Results suggest that PRIII and TRI strains have the gene encoded in their genomes as shown by the PCR product. Presence of this gene was reflected as a band of the expected size on the electrophoresis. TRI showed a product size of $500 \mathrm{bp}$ and PR III showed two bands with a size product of 600 and $800 \mathrm{bp}$, the small band was excised and purified. TR II and PQII showed a product of 900 bp this might be a non-specific annealing and extension to the primers (Figure 4). High quality RNA was obtained in concentrations ranging between $500-1180 \mathrm{ng} / \mu \mathrm{l}$ for diesel and between $1635-3163 \mathrm{ng} / \mu \mathrm{l}$ for glucose. The culture was $10^{6}-10^{7} \mathrm{CFU} / \mathrm{ml}$. In the culture with diesel as the carbon source strains TRI and PRIII showed cDNA-PCR products for alkB to be between 500-600 bp. These results are similar to those obtained by the DNA-PCR for alkB. The expression of alkB at seven day of treatment was evidenced in strains TRI and PRIII according to the sequencing of the bands.

Results showed that TRI and PRIII are expressing the alkane monoxygenase $(\mathrm{alkB})$ gene under diesel growth conditions. In fact these two strains showed the higher biodegradation efficiencies. In contrast no expression was found in the culture with glucose as the carbon source. This result indicates that the alkane degradation pathway is induced by the presence of diesel. Bacteria do not synthesize catabolic enzymes unless the substrate for these enzymes is present [8]. The enzymes involved in the alkane degradation pathway are inducible enzymes that are synthesized in response to a particular substrate [9]. As diesel was the only carbon source added to the culture bacteria needed to produce the enzymes involved in the alkane degradation pathway to obtain energy [10]. According to these findings these bacteria should be able to use the alkane degradation pathway to degrade diesel.

By correlating bacterial growth and diesel degradation, it could be concluded that strains that showed a higher cellular growth at the end of the assay, were those with the highest biodegradation efficiency (TRI, TRIV, PRIII and the consortium). In addition, it may be concluded that the presence and expression of the alkB gene in strains TRI and PRIII indicates that these isolates are employing the alkane pathway in a higher metabolic rate; in fact, these two strains have the highest biodegradation efficiency. Results suggest that bacteria employed in this study belonging to Pseudomonas $s p$ and Pseudomonas stutzeri are useful candidates for diesel bioremediation because they are resistant to diesel compounds, which is an important requirement for bioremediation purposes [11].

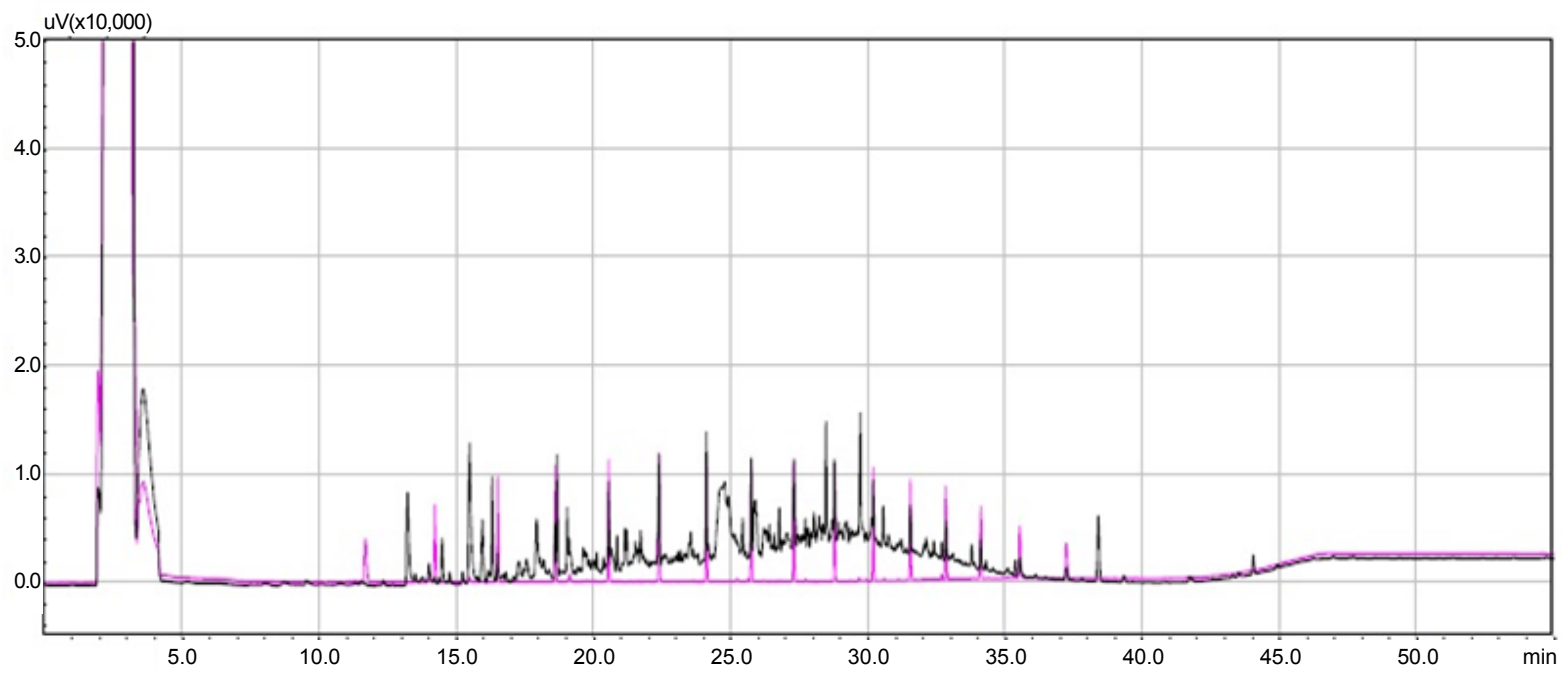

Figure 3: Comparative chromatogram of the consortium after 43 days of incubation in MSM with diesel as the only carbon source and the DRO standard of 25 ppm. 
Citation: Dussán J, Numpaque M (2012)Degradation of Diesel, a Component of the Explosive ANFO, By Bacteria Selected From an Open Cast Coal Mine in La Guajira, Colombia. J Bioprocess Biotech 2:126 doi: 10.4172/2155-9821.1000126

Page 5 of 5

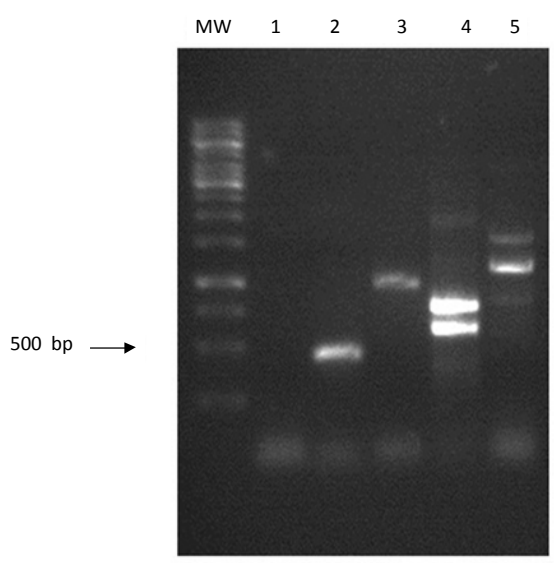

Figure 4: Agarose gel (1\%) electrophoresis of PCR amplification of alkB gene. Primer pair alkB, lane MW: 100bp molecular weight marker, lane 1: negative control, lane 2: TRI, lane 3: TRII, lane 4: PRIII and lane 5: PQII.

\section{References}

1. Vázquez S, Nogales B, Ruberto L, Hernández E, Christie-Oleza J, et al (2009) Bacterial Community Dynamics during Bioremediation of Diesel OilContaminated Antarctic Soil. Microb Ecol 57: 598-610.

2. Hong JH, Kim J, Choi OK, Cho KS, Ryu HW (2004) Characterization of a diesel-degrading bacterium, Pseudomonas aeruginosa IU5, isolated from oil- contaminated soil in Korea. World Journal of Microbiology and Biotechnology 21: 381-384.

3. Ganesh A, Lin J (2009) Diesel degradation and biosurfactant production by Gram-positive isolates. African Journal of Biotechnology 8: 5847-5854.

4. Van Beilen JB, Pnanke S, Lucchini S, Franchini A, Rothlisberger et al. (2001) Analysis of Pseudomonas putida alkane-degradation gene clusters and flanking insertion sequences: evolution and regulation of the alk genes. Microbiology 147: 1621-1630.

5. Ghazali FM, Zaliha RN, Rahman RNZA, Salleh AB, Basri M (2004) Biodegradation of hydrocarbons in soil by microbial consortium. International Biodeterioration \& Biodegradation 54: 61- 67.

6. Zanaroli G, Di Toro S, Todaro D, Varese GC, Bertolotto A, et al. (2010) Characterization of two diesel fuel degrading microbial consortia enriched from a non acclimated, complex source of microorganisms. Microbial Cell Fact 9: 10

7. Shukor MY, Hassan NA, Jusoh AZ, Perumal N, Shamaan NA, et al. (2009) Isolation and characterization of a Pseudomonas diesel-degrading strain from Antarctica. J Environ Biol 30: 1-6.

8. Rojo $F$ (2009) Degradation of Alkanes by bacteria. Environ Microbiol 11 2477-2490.

9. Kato T, Miyanaga A, Kanaya S, Morikawa M (2009) Alkane inducible proteins in Geobacillus thermoleovorans B23. BMC Microbiol 9:60

10. Grundmann O, Behrends A, Rabus R, Amann J, Halder T, et al. (2008) Genes encoding the candidate enzyme for anaerobic activation of n-alkanes in the denitrifying bacterium, strain HxN1. Environ Microbiol 10: 376-385.

11. Kang YS, Park YJ, Jung J, Park W (2009) Inhibitory Effect of Aged Petroleum Hydrocarbons on the Survival of Inoculated Microorganism in a Crude-OilContaminated Site. J Microbiol Biotechnol 19: 1672-1678. 